Int Arch Allergy Appl Immunol 1989;88:I-VI

\title{
Contents, Vol. 88, 1989
}

\section{No. 1-2}

Preface

Sehon, A.H.

Carl Prausnitz Memorial Lecture

Regulation of the IgE Antibody Response

Ishizaka, $\mathrm{K}$

Genes and Products in IgE Response

Emerging Picture of the Receptor with High Affinity for IgE

Metzger, H.; Blank, U.; Kinet, J.-P.; Kochan, J.; Ra, C;

Rivera, J.; White, K 14

Human FceR II and IgE-Binding Factors

Delespesse, G.; Sarfati, M; Hofstetter, H.; Frost, H.; Kilch-

herr, E.; Suter, U 18

Interaction of IgE with Its High-Affinity Receptor. Structural

Basis and Requirements for Effective Cross-Linking

Baird, B.; Shopes, R.J.; Oi, V.T.; Erickson, J.; Kane, P.;

Holowka, D 23

Mediators of Pathological Reactions

A Multifunctional Cytokine (IL-6/BSF-2) and Its Receptor

Hirano, T.; Taga, T.; Yamasaki, K.; Matsuda, T.; Tang, B.;

Muraguchi, A.; Horii, Y.; Suematsu, S.; Hirata, Y.; Yawa-

ta, H.; Shimizu, M.; Kawano, M.; Kishimoto, T 29

Involvement of Tumor Necrosis Factor and Other Cytokines in Immune-Mediated Vascular

Pathology Grau, G.E.; Piguet, P.-F.; Vasalli, P.; Lambert, P.-H. . . 34

Granulocyte/Macrophage Colony Stimulating Factor. A Potent Activation Signal for Mature

Macrophages and Mono-cytes Morrissey, P.J.; Grabstein, K.H.; Reed, S.G.; Conlon, P.J. 40

Cellular Network:

Inflammatory and Allergic Reactions

Preferential Differentiation of Inflammatory Cells by Recom-

binant Human Interleukins

Ishizaka, T.; Saito, H.; Hatake, K.; Dvorak, A.M.; Leifer-

man, K.M.; Arai, N.; Ishizaka, K 46

Cells and Secretagogues Involved in the Human Late-Phase

Response

Charlesworth, E.N.; Iliopoulos, O.; MacDonald, S.M.;

Kagey-Sabotka, A.; Lichtenstein, L.M $\quad 50$

Selectivity of Mediators Released by Eosinophils

Capron, M.; Tomassini, M.; Torpier, G.; Kusnierz, J.-P.;

MacDonald, S.; Capron, A 54 
Eosinophils and Human Disease

Gleich, G.J.; Ottesen, E.A.; Leiferman, K.M.; Ackerman, S.J. 59 T Lymphocytes in Allergen-

Induced Late-Phase Reactions and

Asthma

Frew, A.J.; Corrigan, C.J.; Maestrelli, P.; Tsai, J.-J.; Kuri-

hara, K.; OHehir, R.E.; Hartnell, A.; Cromwell, O.; Kay, A.B. 63 Interactions between

Neurotransmitters and Inflammatory

Cells in the Airways

Pauwels, R.; Joos, G.; Kips, J.; Van Der Straeten, M. . 68

New Approaches to Prevention and Therapy

Interaction of Neuropeptides with Human Mast Cells

Church, M.K.; Lowman, M.A.; Robinson, C; Holgate,

S.T.; Benyon, R.C 70

The Third Histamine Receptor. Highly Potent and Selective Ligands

Arrang, J.M.; Garbarg, M.; Lancelot, J.C.; Lecomte, J.M.; Pollard, H; Robba, M.; Schunack, W.;

Schwartz, J.C. . 79

Structure-Activity Relationships and Effects of Platelet-Acti

vating Factor Antagonists in the Hetrazepine Series

Weber, K.H.; Heuer, H 82

Role of Cytokines and Platelet-Activating Factor in Micro-vascular Immune Injury

Braquet, P.; Hosford, D.; Braquet, M.; Bourgain, R.; Bus-

solino, $\mathrm{F} \quad 88$

Usefulness of Bronchoalveolar Lavage in Asthmatics. The

Right Clinical Practice

Michel, F.B.; Godard, P.; Bousquet, J 101

Genes and Products in IgE Response Short Communications

Interleukin 4 Acts on Both High- and Low-Density Murine B

Cell Subpopulations to Induce IgE and IgGl Synthesis in

vitro

Lebrun, P.; Lucas, A.H.; McKenzie, D.T.; Spiegelberg, H.L. 108 Role of Interleukin 4 and

Gamma Interferon in the Regulation

of Human IgE Synthesis: Possible Alterations in Atopic

Patients

Romagnani, S.; Maggi, E.; Del Prete, G.F.; Parronchi, P.;

Macchia, D.; Tiri, A.; Ricci, M Ill

IV

Contents

Isotype-Specific Suppression of IgE Synthesis in a Human

Myeloma Cell Line (U-266) by an IgE-Binding Protein

Derived from Normal Human Peripheral Blood Cells

Jernberg, H.; Nilsson, G.; Ahlstedt, S.; Nilsson, K 114

Formation of IgE-Binding Factors by Lymphocytes of HIV-

Infected Patients

Carini, C; Margolick, J.; Yodoi, J.; Ishizaka, K 
Interleukin 4 Dependent Induction of IgE Synthesis and CD23 Expression by the Supernatants of a Human Helper T Cell Clone Vercelli, D.; Leung, D.Y.M.; Jabara, H.H.; Geha, R.S. . . 119

Conditioned Media from Cultured Blood Cells of Atopic Indi

viduals Can Induce Differentiation in the Human Baso-

philic Leukemia Cell Line KU812

Matsson, P.; Almlöf, I.; Nilsson, K.; Ahlstedt, S 122

Factors Influencing Basophilic Differentiation of HL-60 Cells

Denburg, J.A.; Hutt-Taylor, S.; Dolovich, J.; Switzer, J.;

Harnish, D.G 126

Mediators of Pathological Reactions Short Communications

Characteristics of Histamine Secretion Induced by Neuro-

peptides: Implications for the Relevance of Peptide-Mast

Cell Interactions in Allergy and Inflammation

Pearce, F.L.; Kassessinoff, T.A.; Liu, W.L 129

Free Radicals Induce Ischemia-Reperfusion Injury and Hista

mine Release in the Isolated Guinea Pig Heart

Masini, E.; Gianella, E.; Palmerani, B.; Pistelli, A.; Gam-

bassi, F.; Mannaioni, P.F 132

Prostaglandin H Synthetase Activates Xenobiotics into Free Radicals: Histamine Release and

Biochemical Characteristics

Masini, E.; Gianella, E.; Palmerani, B.; Pistelli, A.; Gam-

bassi, F.; Mannaioni, P.F 134

Ultraviolet A Inhibits Histamine Release from Human Periph

eral Leukocytes

Ring, J.; Przybilla, B.; Eberlein, B 136

Chronic Glomerulonephritis: Inflammatory Mediators Stimu

late the Collagen Synthesis in Glomerular Epithelial Cells

Hänsch, G.M.; Torbohm, I.; Rother, K 139

Conjunctival Provocation Test as a Model for the Study of

Allergy and Inflammation in Humans

Bonini, S.; Bonini, St.; Berruto, A.; Tomassini, M.; Carle-

simo, S.; Bucci, M.G.; Balsano, F 144

PAF-Acether and Experimental Anaphylaxis as a Model for Asthma

Pretolani, M.; Lellouch-Tubiana, A.; Lefort, J.; Bachelet, M.;

Vargaftig, B.B 149

Effect of Long-Term Administration of Platelet-Activating Factor on Pulmonary Responsiveness and Morphology in the Guinea Pig Mencia-Huerta, J.-M.; Touvay, C; Pfister, A.; Braquet, P. 154 Effect of Platelet-Activating Factor on Monocyte Activation

and Production of Tumor Necrosis Factor

Bonavida, B.; Mencia-Huerta, J.-M.; Braquet, P 157

Effect of Long-Term Treatment with Platelet-Activating Factor on Cytokine Production by Rat

Spleen Cells Pignol, B.; Hénane, S.; Mencia-Huerta, J.-M.; Braquet, P. 161

Allergens

Molecular Genetics of Human Immune Responsiveness to

Lolium perenne (Rye) Allergen, Lol p III (Short Communi 
cation)

Ansari, A.A.; Freidhoff, L.R.; Marsh, D.G 164

Clonal Analysis of the Cellular Immune Response to the

House Dust Mite Dermatophagoides farinae

O’Hehir, R.; Young, D.; Kay, A.B.; Lamb, J 170

Allergens of the House Dust Mite Dermatophagoides farinae. II. Immunological Characterization of Four Allergenic Molecules

Yamashita, N.; Haida, M.; Suko, M.; Okudaira, H.; Miya

moto, $\mathrm{T} \quad 173$

Age-Dependent Changes of Isotype and Idiotype Expression in the Antibody Response to the Phosphorylcholine Hapten in BALB/c Mice

Gerber, V.; Ponnappan, U.; Heusser, C.H.; Cinader, B.;

Blaser, K $\quad 176$

Specificities of IgE and IgG Antibodies in Patients with Birch Pollen Allergy

Jarolim, E.; Rumpold, H.; Endler, A.T.; Schlerka, G.; Eb-

ner, H.; Scheiner, O.; Kraft, D 180

Inhalant Allergy in Asthmatic Children: Skin Prick Test, Radioallergosorbent Test and

Chemiluminescent Assay Compared with Allergen Levels in Their Mattress Dusts Price, J.A.;

Reiser, J.; Longbottom, J.L.; Warner, J.O. .. 183

Characterization of Immunologically Important Antigens and Allergens of Aspergillus fumigatus

Longbottom, J.L.; Harvey, C; Taylor, M.L.; Austwick,

P.K.C.; Fitzharris, P.; Walker, C.A 185

Cellular Network:

Inflammatory and Allergic Reactions

Release of High Molecular Weight-Neutrophil Chemotactic

Activity from Human Tissues, Cells and Secretion

Nagakura, T.; Onda, T.; Akimoto, K; Nagakura, H.; Tana-

ka, K.; Ohno, K; Sudo, T.; Iikura, Y 187

Comparative Studies of Human Eosinophil Migration towards

Platelet-Activating Factor and Leukotriene B4

Czarnetzki, B.M.; Csatò, M 191

Flow-Cytometric Analysis of Increased IgE Uptake by Normal

Eosinophils following Activation with PAF-Acether and

Other Inflammatory Mediators

Walsh, G.M.; Nagakura, T.; Iikura, Y

194

Effect of Histamine on Chemotaxis and Phagocytosis of $\mathrm{Hu}$

man Alveolar Macrophages and Blood Monocytes

Radermecker, M.; Bury, T.; Saint-Remy, P 197

IgE Receptors from Rat Intestinal Mucosal and Peritoneal

Mast Cells Show Mast Cell Subtype-Specific Differences

Swieter, M.; Chan, B.M.C.; Lee, T.D.G.; Rimmer, C.J.;

Froese, A.; Befus, D 200

Effect of Monoclonal Antihuman IgE on Recombinant

IgE(3or_376) Inhibition of Specific IgE Histamine Release

Glovsky, M.M.; Kebo, D.; Helm, B.A.; Horvath, S.; Ri

chards, J.A.; Chretien, I.; Bencherau, J.; Gould, H 203 
Potential Role of Anti-IgE Antibodies in vivo

Stadler, B.M.; Nakajima, K; Yang, X.; de Week, A.L. . . 206

Nasal Mast Cell Response to Natural Allergen Exposure

Enerbäck, L.; Karlsson, G.; Pipkorn, U 209

Contents

$\mathrm{V}$

Inhibition of Human Eosinophil Chemotaxis and of the IgE-Dependent Stimulation of Human Blood Platelets by Ce-tirizine

De Vos, C; Joseph, M.; Leprevost, C; Vorng, H.; Tomas-

sini, M.; Capron, M.; Capron, A 212

Modulation by Drugs of Eosinophil Recruitment Induced by

Immune Challenge in the Rat. Possible Roles of Interleu-

kin 5 and Platelet-Activating Factor

Etienne, A.; Soulard, C; Thonier, F.; Braquet, P 216

Effect of the Platelet-Activating Factor Antagonist BN 52021 on Human Natural Killer Cell

Cytotoxicity Mandi, Y.; Farkas, G.; Koltai, M.; Beladi, I.; Braquet, P. 222

Formation of Oedema and Accumulation of Eosinophils in the

Guinea Pig Lung. Inhibition by Inhaled Beta-Stimulants

Fügner, A 225

Antiasthmatic Effects of Onions. Prevention of Platelet-Acti

vating Factor Induced Bronchial Hyperreactivity to Hista-

mine in Guinea Pigs by Diphenylthiosulfinate

Dorsch, W.; Scharff, J.; Bayer, T.; Wagner, H

228

Effect of Ricin on the Proliferation of Rat Spleen and Mesen-

teric Lymph Node Cells

Kemeny, D.M.; Thorpe, S.C.; Holt, P.G 231

Effect of Neonatal or Later Capsaicin Treatment on Bronchial Reactivity in Sensitized Rats.

Relation to Humoral Changes Nilsson, G.; Alving, K.; Lundberg, J.M.; Ahlstedt, S. . . 234

Relationship between Bacteria and IgE

Levy, D.A.; Dorat, A.; Pinel, A.-M.; Normier, G.; Dus-

sourd DHinterland, L.; David, B 237

Effect of Nedocromil Sodium on S 62 -Induced Airway Hyper-

responsiveness and Citric Acid-Induced Cough in Dogs

Eady, R.P.; Jackson, D.M 240

Study of the Antiallergic Component of Inosine Pranobex

(Inosiplex, Isoprinosine)

Schmutzler, W.; Neukirch, B.; Ziesche, R 244

$\mathrm{IgG}$ and IgE Antibodies after Immunotherapy with Bee and Wasp Venom

Kemeny, D.M.; Lessof, M.H.; Patel, S.; Youlten, L.J.F.;

Williams, A.; Lambourn, E 247

How to Prevent Allergic Disease. I. Study of Specific IgE, IgG, and IgG4 Antibodies in Serum of Pregnant Mothers, Cord Blood, and Infants

Iikura, Y.; Akimoto, K.; Odajima, Y.; Akazawa, A.; Naga-

kura, T250 
Inhibition of Histamine and Prostaglandin D2 Release from Human Lung Mast Cells by Ciclosporin A Triggiani, M.; Cirillo, R.; Lichtenstein, L.M.; Marone, G. 253

Immune Reactions in a Changing Environment. USA Initia

tives

Goldstein, R.A 256

Author Index 259

No. 3

Original Paper

Release of Allergens from Cladosporium Conidia

Bouziane, H.; Latgé, J.P.; Mecheri, S.; Fitting, C; Prévost,

M.C 261

Suppression by Tetrandrine of Human Platelet Aggregation Induced by Platelet-Activating

Factor and Other Stimulants

Teh, B.S.; Ioannoni, B.; Seow, W.K.; McCormack, J.G.;

Thong, Y.H 267

Role of Local IgA Antitoxin-Producing Cells for Intestinal Pro

tection against Cholera Toxin Challenge

Lycke, N.; Bromander, A.K.; Holmgren, J 273

Kinetics and Isotype Distribution of Parasite-Specific Anti

body Responses in the Spleen of Mice during Primary

Infection with Schistosoma mansoni. Studies at the Single-

Cell Level

Czerkinsky, C; Nilsson, L.-Å.; Ouchterlony, Ö 280

Neutral Endopeptidase Modulates Tachykinin-Induced In crease in Vascular Permeability in Guinea Pig Skin

Iwamoto, I.; Ueki, I.F.; Borson, D.B.; Nadel, J.A 288

Proliferation of Interleukin 2 Dependent Cytotoxic T Cell

Line Cells. Different Protein Kinase C Activators Achieve

the Same Maximal Promotion, but with Distinct Dose-

Response Profiles

Gavériaux, C; Loor, F 294

Production of Interleukin-1-Alpha and -Beta by Human Pe

ripheral Polymorphonuclear Neutrophils

Goh, K; Furusawa, S.; Kawa, Y.; Negishi-Okitsu, S.; Mizo-

guchi, M 297

Serum Antibodies to Pseudomonas pseudoalcaligenes in Metal Workers Exposed to Infected

Metal-Working Fluids Mattsby-Baltzer, I.; Edebo, L.; Järvholm, B.; Lavenius, B. 304

Epstein-Barr Virus Transformed by Human B Lymphocytes

Endocytose Autologous and Heterologous Red Blood Cells

Garzelli, C; Marchetti, A.; Pacciardi, A.; Puglisi, C; Baso-

lo, F 312

Intra-Epithelial Lymphocytes and Non-Lymphoid Cells in the Human Nasal Mucosa

Hameleers, D.M.H.; Stoop, A.E.; van der Ven, I.; Biewen-

ga, J.; van der Baan, S.; Sminia, T 317

Biochemical Characterization of an Antigen-Specific Suppressor T Cell Factor Matsushita, E.;

Sumida, T.; Tagawa, M.; Taniguchi, M. . 323 
Functional Differences of Human Basophils with Different Densities

Morita, Y.; Asakawa, M.; Hirai, K; Takaishi, T.; Miyamo

to, $\mathrm{T} \quad 332$

Experimental Drug-Induced Allergic Nephritis Mediated by Antihapten Antibody

Joh, K; Shibasaki, T.; Azuma, T.; Kobayashi, A.; Miyaha-

ra, T.; Aizawa, S.; Watanabe, N 337

Short Communications

Local Murine Recombinant Gamma Interferon Enhances the

Acquisition of Allergic Contact Dermatitis in the Mouse

Maguire, H.C., Jr.; Guidotti, M.; Weidanz, W.P 345

VI

Contents

Alterations in Function and Subpopulations of Peripheral

Blood Mononuclear Leukocytes in Children with Portal

Hypertension. Leukocyte Subtypes and Function in Portal

Hypertension

Ferrante, A.; Davidson, G.P.; Beard, L.J.; Goh, D.H.B. . 348 Phenotypic and Cellular Changes

Associated with Loss of

Antigen-Induced Function in Epstein-Barr Virus-Specific

Human T-Cell Hybrids

Gallagher, G 353

Ability of Alpha (but Not Beta) Form Interleukin-1 to Support

DNA Synthesis in Human Tonsillar B Cells

Gallagher, G.; Christie, J.F.; Stimson, W.H 357

Numbers and Heterogeneity of Mast Cells in the Male Genital

Tract of the Rat

Fritz, F.J.; Pabst, R 360

Mast Cell Heterogeneity in the Small Intestine of Normal,

Gnotobiotic and Parasitized Pigs

Pabst, R.; Beil, W 363

Cytochemical Evidence of Lack of Basic Protein in Mucosal

Mast Cells of the Small Intestine in the Rat

Lunardi, L.O.; Jamur, M.C.; Vugman, I.; Gonçalves, R.P. 367 Microfilament-Associated Local

Degranulation of Rat Peritoneal Mast Cells

Mio, M.; Tasaka, K 369

Book Reviews $\quad 372$

No. 4

Original Paper

Increased Hyaluronan (Hyaluronic Acid) Levels in Broncho-alveolar Lavage Fluid after

Histamine Inhalation Söderberg, M.; Bjermer, L.; Hällgren, R.; Lundgren, R. . 373

Inhibition of cAMP Increase by an Antigen-Allergic Agent, NCO-650, during Histamine Release

Takei, M.; Matumoto, T.; Endo, K.; Muramatu, M. ... 377

Budesonide Reduces Sensitivity to Antigen but Does Not Alter

Baseline Tone or Responsiveness to Carbachol, Terbuta-

line, and Enprofylline in IgE-Sensitized Guinea-Pig Tra 
cheae

Persson, C.G.A.; Andersson, P.T.; Gustafsson, B 381

Occurrence of Histamine-Production-Increasing Factor in the

Postanaphy-lactic Phase of Allergic Inflammation

Hirasawa, N.; Ohuchi, K.; Kawarasaki, K.; Watanabe, M.;

Tsurufuji, S 386

Effect of Cyclophosphamide Pretreatment on Defective De-layed-Type Hypersensitivity in Autoimmune-Prone MRL Mice

Okuyama, H.; Matsunaga, T.; Kobayashi, S.; Hashimoto,

Y.; Kawaguchi, Y.; Yamamoto, K 394

Comparative Analysis of Physicochemical and Immunochem-

ical Properties of the Two Major Allergens from Dermato-

phagoides pteronyssinus and the Corresponding Allergens

from Dermatophagoides faunae

Yasueda, H.; Mita, H.; Yui, Y.; Shida, T 402

Quantitative Rather Than Qualitative Differences between Monocytes with Respect to IgE Fc

Receptor Expression as Studied by Flow Cytofluorometry Hed, J.; Halldén, G.; Johansson,

S.G.O.; Larsson, P. . . . 408

Human Seminal Plasma Suppresses Delayed-Type Hypersen

sitivity Responses to Intravaginally Deposited Sheep Red

Blood Cells and Sperm: Separation of Immunosuppressive

Factors

Lee, H.-K.; Ha, T.-Y 412

Detection of Antigens from Gram-Negative Bacilli in Urine of

Children with Urinary Tract Infections. I. Common Anti

gen of Enterobacteriaceae

Kim, D.S.; Gorzynski, E.A.; Milgrom, F 420

Detection of Antigens from Gram-Negative Bacilli in Urine of

Children with Urinary Tract Infections. II. Thermostable

Bacterial Proteins

Kim, D.S.; Gorzynski, E.A.; Milgrom, F 427

Strong Delayed-Type Hypersensitivity Induced against House

Dust Mite Antigens in the Mice

Nakano, Y.; Yoshida, M.; Shibata, T 434

Nedocromil Sodium Inhibits IgE- and IgG-Related Antigen-

Induced Contraction in Guinea-Pig Trachea

Bertrand, C; Tschirhart, E.; Landry, Y 439

Potentiation of the Stimulatory Capacity of Pokeweed Mito-

gen via Its Binding to Autologous Erythrocytes

Uiterdijk, H.G.; Doekes, G.; de Vreede, T.M.; de Vries, E.;

Cats, A $\quad 447$

Effect of Eicosapentaenoic Acid Rich Menhaden Oil and Max-

EPA on the Autoimmune Disease of Mrl/1 Mice

Westberg, G.; Tarkowski, A.; Svalander, C 454

Effects of Combined Receptor Antagonists of Leukotriene

D4(LTD4) and Platelet-Activating Factor (PAF) on Rhesus 
Airway Responses to LTD4, PAF and Antigen

Patterson, R.; Harris, K.E.; Bernstein, P.R.; Krell, R.D.;

Handley, D.A.; Saunders, R.N 462

Short Communications

Serum Neopterin in Patients with X-Linked and Acquired 'Common Variable'

Hypogammaglobulinaemia Harland, C; Shah, T.; Webster, A.D.B.; Peters, T.J. ... 471

Effect of Systemic and Orally Administred Iota-Carrageenan

on Ovalbumin-Specific Antibody Response in the Rat

Coste, M.; Dubuquoy, C; Tome, D 474

Author Index 477 